\title{
Behaviour of Engineered Slopes in Flysch Rock Mass
}

\author{
Ž. Arbanas Civil Engineering Institute of Croatia, University of Rijeka, Croatia
}

M. Grošić Geotech Ltd, Croatia

G. Briški Rijekaprojekt GI Ltd, Croatia

\begin{abstract}
This paper presents some experiences during the reinforced cut construction in the flysch slopes for the Adriatic motorway near the city of Rijeka, Croatia. The Cretaceous and the Paleogene limestone are situated on the top of the slope, while the Paleogene flysch crops are on the lower slope and in the bottom of the Draga Valley where the motorway is located. Unlike limestone rocks at the top of the slope, flysch rock mass is almost covered by colluvial deposits, residual soils and talus breccia. The major part of the motorway was constructed by cutting of the slopes in flysch rock mass. Stability of the slopes was ensured by the reinforcement of the rock mass with rockbolts and appropriate supporting system. The self boring rockbolts, in combination of multi-layered sprayed concrete or reinforced grid construction, were used. The deep boring drains were installed for dissipation of ground water collected at contact of permeable cover and impermeable flysch rock mass. The interactive rock mass cutting design, based on the observational methods, was introduced during the construction. The initial design of slopes construction was based on the recommended Hoek-Brown criteria for heterogeneous rock mass such as flysch. Design properties of the flysch rock mass were adopted on the geological strength index (GSI) concept. During the phase of interactive design the appropriate measured equipment was installed. This active design approach has allowed the designer, based on the rock mass conditions and monitoring results, to change the support system in the slopes at some unfavourable locations. The measured values and the back analysis enabled the establishment of real rock mass strength parameters and deformability modulus.
\end{abstract}

\section{Introduction}

The geotechnically most challenging section of the Adriatic motorway was constructed in the Draga Valley near the city of Rijeka, Croatia. During the period from 2004 to 2006, the section of the Adriatic motorway through the Draga Valley near Rijeka, was constructed. This segment of the Adriatic motorway is only $6.8 \mathrm{~km}$ in length but very demanding in geotechnical terms and, because of significant number of structures (three junctions, two tunnels and several viaducts), very expensive as well. The geological fabric of the Draga Valley is very complex. The Cretaceous and the Paleogene limestones are situated on the top of the slope, while the Paleogene flysch crops are on the lower slope and on the bottom of the Draga Valley where the motorway is located. Unlike limestone rocks at the top of the slope, flysch rock mass is completely covered by colluvial deposits, residual soils and talus breccia.

The major part of the motorway was constructed by cutting in flysch rock mass. Stability of the cuts was established by the reinforcement of the rock mass with rockbolts and appropriate supporting systems. As appropriate solutions, the self boring rockbolts with a combination of multi-layered sprayed concrete as a first stage and reinforced concrete grid construction as a final stage, were used. Due to low value of flysch rock mass strength, extra attention was dedicated on the interaction between rock mass and rockbolts.

The interactive design of rock mass cutting, based on the observational methods, was introduced during the construction. The initial design was done based on the soil and rock parameters, obtained from GSI classification of flysch rock mass and laboratory testing of rocks and soils The appropriate measured equipment was installed before and during the construction - vertical inclinometers, horizontal deformeters, piezometers and geodetic surveying. This active design approach has allowed the designer, based on the rock mass conditions and monitoring results, to change the support system at some unfavourable locations. The measured values and the back analysis enabled the establishment of real rock mass strength parameters and deformation modulus. In this paper, we are presenting our experience with the applying of the observational 
method during the construction of the reinforced slopes in flysch rock mass. The methods of determining of soil and flysch rock properties and the numerical modelling of support systems, are described. Results of observations on the installed monitoring equipment are presented and compared with predicted values.

\section{Geotechnical properties of flysch rock mass}

The geological fabric of steep slopes of the Draga Valley is limestone rock mass. At the bottom of the valley, there are deposits of Paleogene flysch mainly made of siltstones with rare layers of sand, marl, and breccia. Flysch rock mass (Figures 1 and 2) is covered with slope formations, which tend to slide and denude (Arbanas et al., 1994). Usual geotechnical cross section consists of three layers, clay cover made after disintegration of flysch rock mass (residual soil) or brought by gravitation from hypsometrically higher parts of the slope; layers of weathered flysch deposits with variable characteristics of weathering decreasing with depth; and fresh flysch zone.

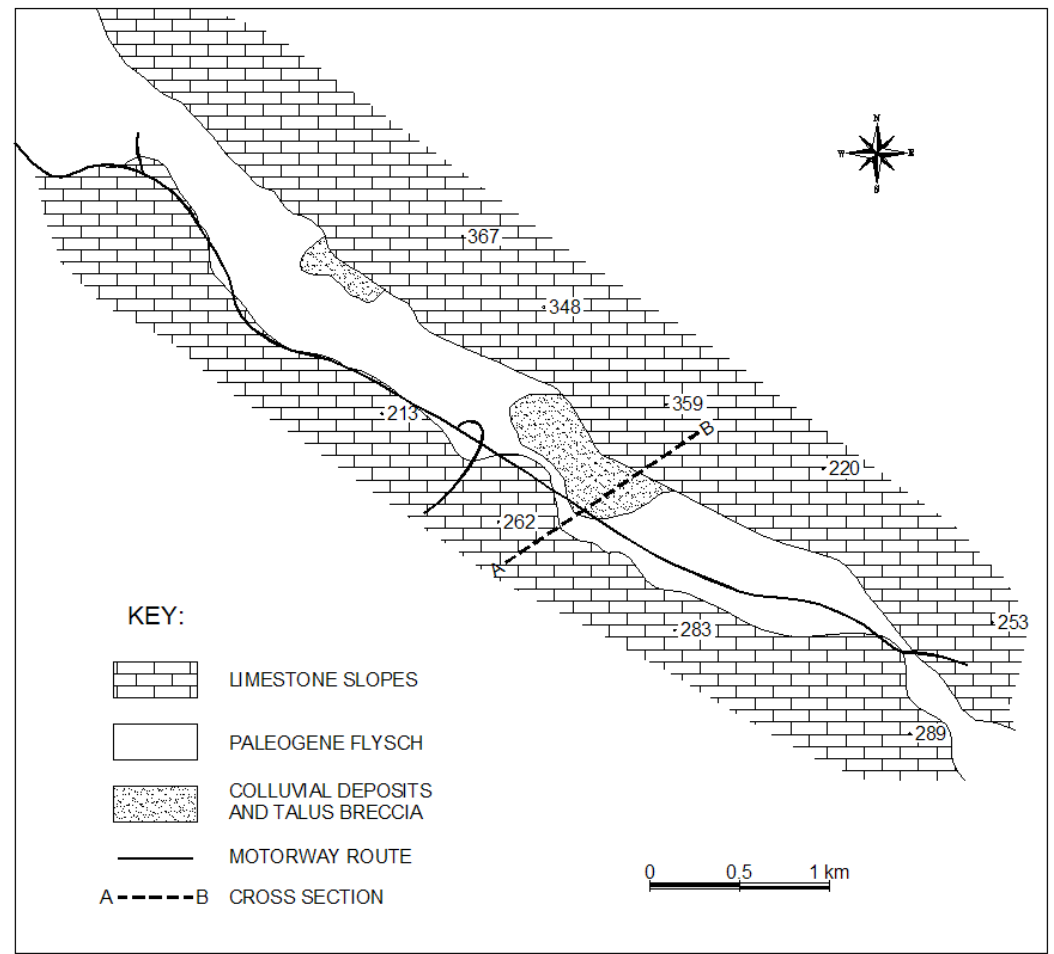

Figure 1 Schematic engineering-geological map of the Draga Valley (Arbanas et al., 1994)

The rock mass is mainly made of siltstones which exhibit visual transfer from a completely weathered (CW) zone with yellow colour, through highly weathered (HW), moderately weathered (MW) and slightly weathered (SW) deposits all the way to fresh rock mass (F) (Table 1, (ISRM, 1981a)). In the zone of completely weathered siltstones, the rock mass has disintegrated, but the original structure of the rock mass stayed intact (ISRM, 1981a, b). The layers of fresh siltstones have no visible weathering marks except colour change on the main discontinuity surfaces. During decomposition of singular weathering zones of the flysch rock mass, along with a visual check of the material from boreholes, significant contribution came from results of geophysical measurements using surface seismic refraction methods and the down-hole method (Arbanas et al., 2007a).

The determination of geotechnical properties of the flysch rock mass, during geotechnical examination works, were disabled because of the flysch rock mass behaviour. During boring, it was difficult to get undisturbed samples, because of rock mass disintegration in HW to MW siltstones. The significant is also a sudden degradation and disintegration of SW to F siltstones after removal of geostatic loads and exposure to air and water during boring. The consequence of these processes in F siltstones was a very small number of undisturbed samples for laboratory uniaxial strength tests. The uniaxial strength of SW to F siltstones obtained from laboratory uniaxial test varied from 8 to $32 \mathrm{MPa}$. Obtaining the undisturbed samples in $\mathrm{CW}$ to 
MW was not possible. The main test comprised of was the point load test (PLT), where samples, obtained by boring, were used without further processing and almost immediately after sampling (ISRM, 1985). The disadvantage of PLT is surely large dispersion of the results, which especially occur with weak rock masses such as flysch. The dispersion of results is influenced by rock mass layers, layers orientation during sampling, sample size, as well as weathering of flysch rock mass. However, regardless of given disadvantages, the use of the PLT method is recommended in case of the lack of more reliable testing, lack of appropriate representative samples and in combination with a detailed description of tested samples of flysch rock mass. The acceptable values of uniaxial strength from PLT must be based on the statistical mean from numerous tests excluding extreme values. Test results of PLT on F siltstone samples showed that corresponded uniaxial strength of these materials is from 10 to $15 \mathrm{MPa}$, and in extreme cases to $20 \mathrm{MPa}$. The corresponded uniaxial strength of MW to SW samples showed values < $2 \mathrm{MPa}$, and these values obtained from the PLT are not confident and unacceptable for engineering analyses without adequate precautions.

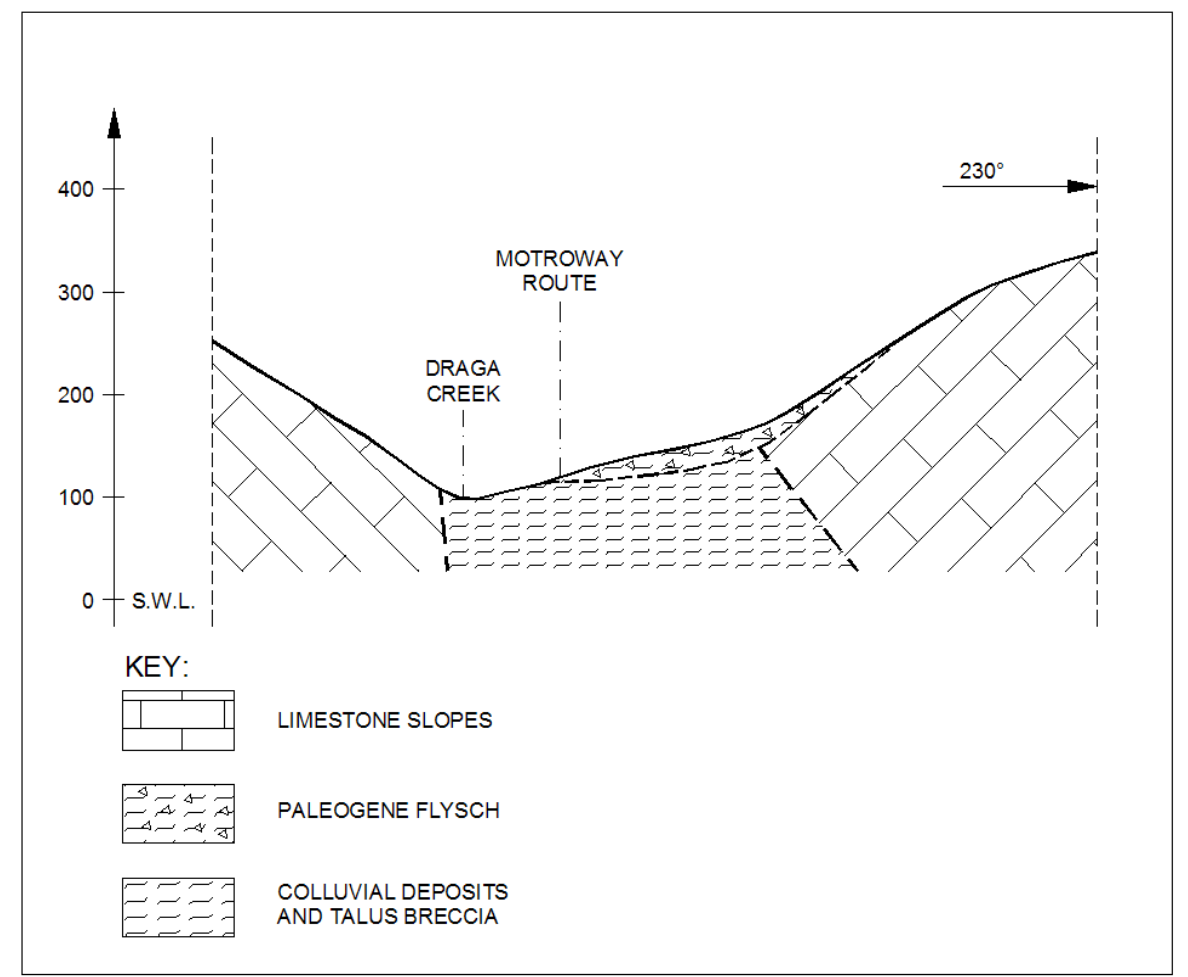

Figure 2 Schematic engineering-geological cross-section of the Draga Valley (Arbanas et al., 1994)

Determination of the shear strength criteria and deformation modulus of flysch rock mass, was based on the geological strength index (GSI) concept (Hoek, 1994; Hoek et al., 1995; Hoek et al., 1998; Marinos and Hoek, 2000; Marinos and Hoek, 2001; Marinos et al., 2005). Based on recommendations from Marinos and Hoek (2001), F siltstone flysch rock mass is placed in group E to H, with GSI values from 30 to 10 as shown in Figure 3. The strength parameters are found to decrease with increase of weathering of siltstones in flysch rock mass, but existing GSI estimations don't include the weathering grade as an influence parameter which could affect correction of the GSI value. This effect points out the need for further evaluation of the GSI concept for various weathering categories of rock mass liable to weathering.

For determination of flysch rock mass strength, the Hoek-Brown failure criterion is used (Hoek et al., 2002) with uniaxial strength value $\left(\sigma_{\mathrm{c}}\right)$ of $\mathrm{F}$ siltstone rock mass of $10 \mathrm{MPa}$ and disturbance factor (D) of 0.7 , which corresponds to machine excavation. In $\mathrm{CW}$ flysch rock mass on the contact with clayey cover the MohrCoulomb criterion is adopted with strength parameters equal to the parameters in the colluvial deposits and residuals soils $\left(\phi=26^{\circ}, \mathrm{c}=6 \mathrm{kPa}\right)$. 
Table 1 Weathering grades of rock mass (ISRM, 1981a)

\begin{tabular}{|c|c|c|c|}
\hline Term & Symbol & Description & Grade \\
\hline Fresh & $\mathrm{F}$ & $\begin{array}{l}\text { No visible sign of rock material weathering; perhaps slight } \\
\text { discolouration on major discontinuity surfaces. }\end{array}$ & I \\
\hline $\begin{array}{l}\text { Slightly } \\
\text { weathered }\end{array}$ & SW & $\begin{array}{l}\text { Discolouration indicates weathering of rock material and } \\
\text { discontinuity may be somewhat weaker externally than in } \\
\text { its fresh condition. }\end{array}$ & II \\
\hline $\begin{array}{l}\text { Moderately } \\
\text { weathered }\end{array}$ & MW & $\begin{array}{l}\text { Less than half of the rock material is decomposed and/or } \\
\text { disintegrated to a soil. Fresh or discoloured rock is present } \\
\text { either as a continuous framework or as core stones. }\end{array}$ & III \\
\hline $\begin{array}{l}\text { Highly } \\
\text { weathered }\end{array}$ & HW & $\begin{array}{l}\text { More than half of the rock material is decomposed and/or } \\
\text { disintegrated to a soil. Fresh or discoloured rock is present } \\
\text { either as a discontinuous framework or as core stones. }\end{array}$ & IV \\
\hline $\begin{array}{l}\text { Completely } \\
\text { weathered }\end{array}$ & $\mathrm{CW}$ & $\begin{array}{l}\text { All rock material is decomposed and/or disintegrated to a } \\
\text { soil. The original mass structure is still largely intact. }\end{array}$ & V \\
\hline Residual soil & $\mathrm{RS}$ & $\begin{array}{l}\text { All rock material is converted to a soil. The mass structure } \\
\text { and material fabric are destroyed. There is a large change in } \\
\text { volume, but the soil has not been significantly transported. }\end{array}$ & VI \\
\hline
\end{tabular}

\begin{tabular}{l}
\hline GSI FOR HETEROGENEOUS ROCK MASSES SUCH AS FLYSH \\
(Marios.P and Hoek. E, 2000) \\
From a description of the lithology, structure and surface conditions (particularly of the \\
bedding planes), choose a box in the chart. Locate the position in the box that \\
corresponds to the condition of the disconitnuities and estimate the average value \\
of GSI from the contours. Do not attempt to bee precise. Quoting a range from \\
33 to 37 is more realistic than giving GSI=35. Note that Hoek-Brown criterion does not \\
apply to structurally controlled failures. Where unfavourably oriented continuous \\
weak planar discontinuities are present, these will dominate the behaviour of the \\
rock mass. The strength of some rock masses is reduced by the presence of \\
groundwater and this can be allowed for by a slight shift to the right in the oolumns for \\
fair, poor and very poor conditions. Water pressure does not change the value of GSI \\
and it is dealt with by using effective stress analysis. \\
COMPOSITION AND STRUCTURE
\end{tabular}

Figure 3 Properties of flysch rock mass in the Draga Valley 
Deformation characteristics of siltstone and other flysch components are even harder to determine than strength parameters. It is the usual way to determine deformation modulus using suggested relations and values based on the GSI concept (Marinos and Hoek, 2000; Marinos and Hoek, 2001; Hoek et al., 2002; Marinos et al., 2005). Deformation modulus of flysch rock mass, obtained from back stress-strain analysis based on in situ measurement results show significantly lower values of elastic modulus (E) of F siltstones, which ranges from 80 to $200 \mathrm{MPa}$ (Arbanas et al., 2007a).

There are other significant problems with heterogeneous rock mass such as flysch liable to weathering and sudden degradation and disintegration after removing geostatic load and exposing to air and water on surface atmosphere conditions including:

- Influence of weathering on the strength criterion.

- Time dependence of weathering on the strength criterion.

- Loosening of deformation characteristics as function of the time weathering process.

These unknowns are included in high safety factors with conservative approaches, based on confined experiences, but these problems need further detailed investigations in the future.

\section{Support systems and reinforcement of flysch rock mass}

During the construction of the described section of the Adriatic motorway, on the major part of the road, the cutting in flysch rock mass is designed and executed. The cut stability is ensured by the reinforcement of the cuts by rockbolts and appropriate supporting system. According to executed geotechnical investigation works, the use of rock mass reinforcement system was specified in slightly weathered to fresh rock mass, while in highly weathered parts of rock mass the change of geometry is specified, with cuts in appropriate stable slopes.

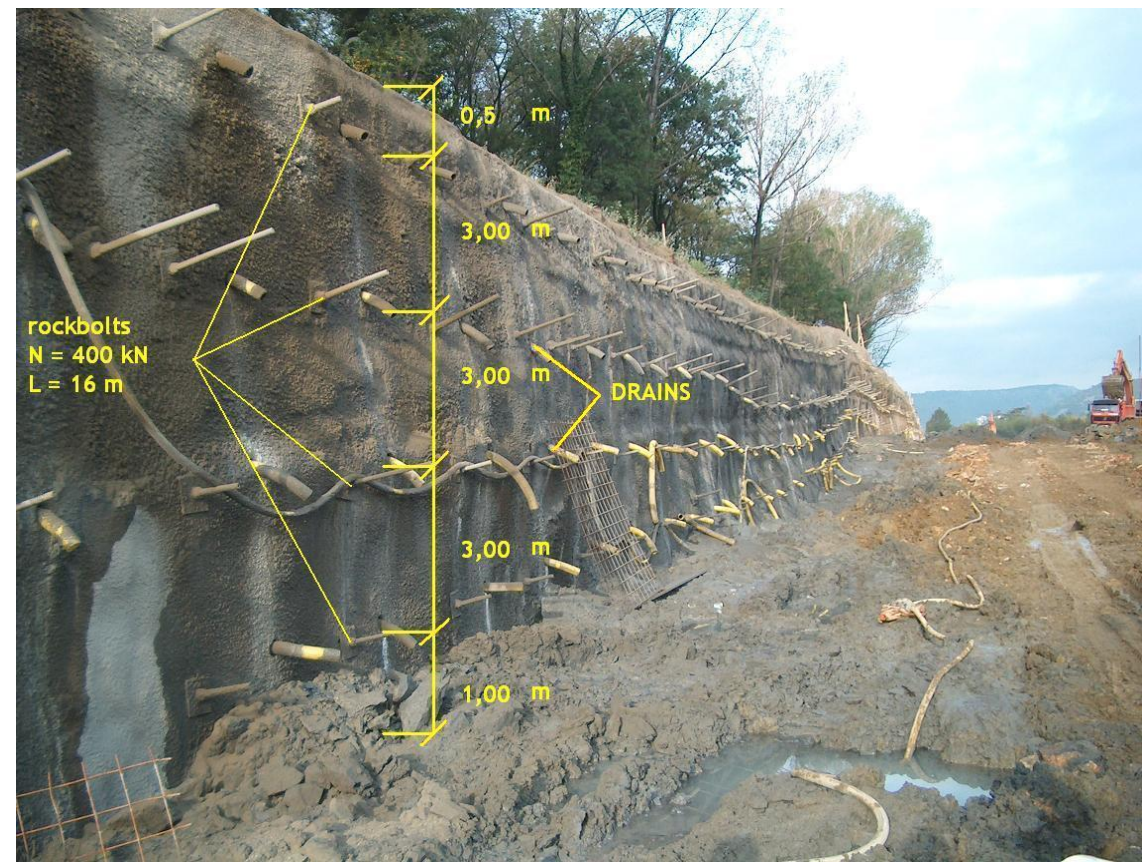

Figure 4 The cut in flysch rock mass during support system construction

Because of steep slopes it wasn't possible to select a stable geometry on most cuts in the flysch rock mass without additional reinforcement or support system. The support system was designed in two phases. The first phase was predicted rockbolt reinforcement system with multilayer sprayed concrete to enable stable excavation of the cuts with relatively low factors of safety (FOS $=1.2$ to 1.25 ). The sprayed concrete consisted of three $5 \mathrm{~cm}$ thick layers reinforced with two steel meshes. The selfboring rockbolts were 9,12 and 15 metres long. 
The capacity of the steel bars was 330 to $500 \mathrm{kN}$, installed on vertical and horizontal distances of $2 \times 2 \mathrm{~m}$. In the second phase, a stiff concrete retaining construction was applied to fix a relatively soft primary reinforcement system.

The primary reinforcement systems were performed by excavation in the working stages, in longitudinal stories of $3 \mathrm{~m}$ height and a successive construction of a three-layered sprayed concrete support system reinforced by self-boring rockbolts from top to bottom of the excavation. The stability of the cut in the flysch rock mass without an applied support system is time dependent, so the working stages are relatively very short, excavation in one day, first layer of sprayed concrete and rockbolts installation in the next two days, and additional two layers of sprayed concrete in the following two days. Simultaneously with reinforcement, support system deep drainage boreholes were drilled (drains $60 \mathrm{~mm}, 2$ to $5 \mathrm{~m}$ depth and selfboring drains $146 \mathrm{~mm}, 6$ to $9 \mathrm{~m}$ depth) to allow dissipation of pore pressure and the lowering of ground water in the cuts (see Figures 4 and 5).

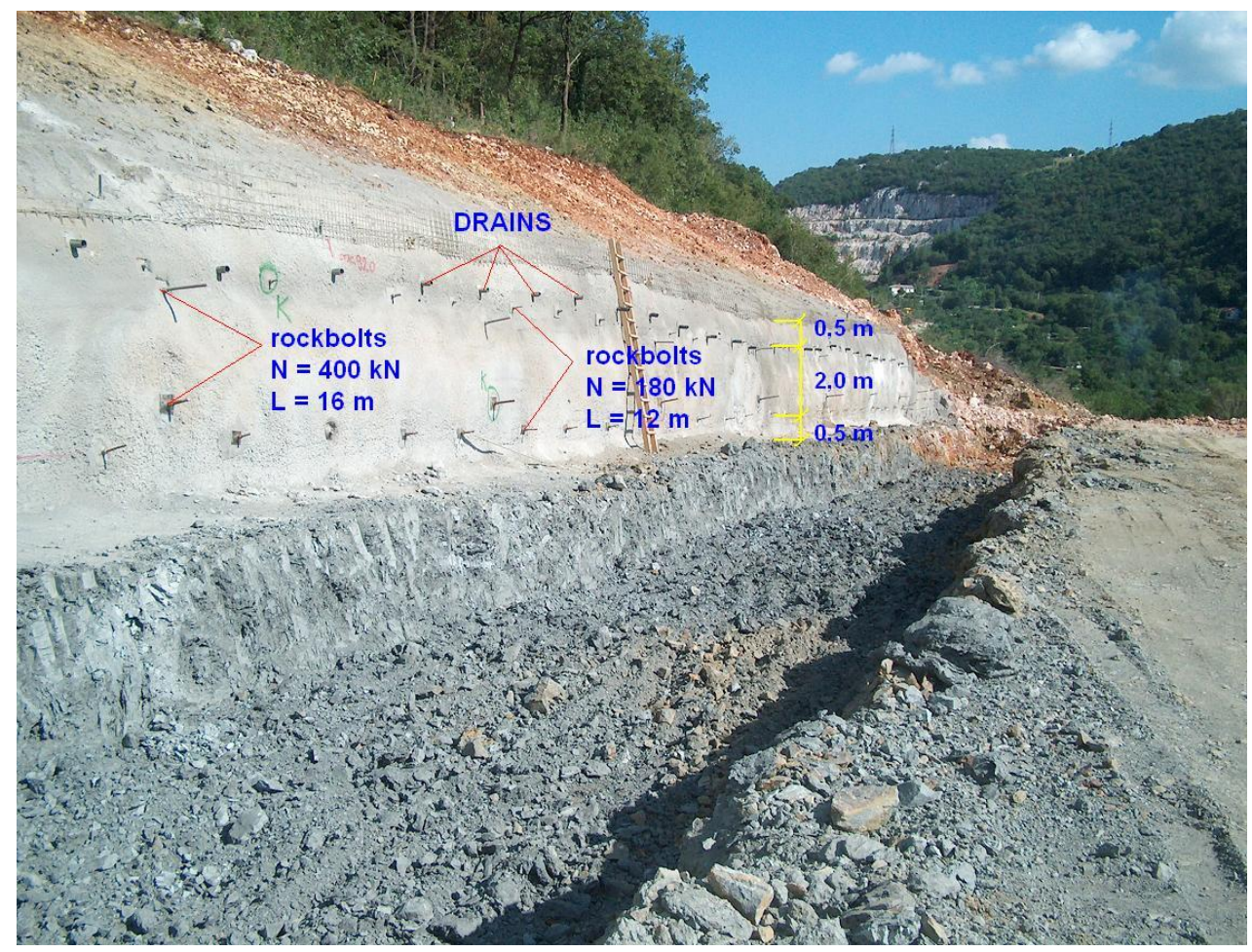

Figure 5 Excavation in flysch rock mass below the executed support system

During the cut construction a monitoring system was established. The monitoring system included measurement of deformation in horizontal deformeters and vertical inclinometers, geodetic surveying and measuring of the force rockbolts by installed load cells. The measurements were performed after each construction stage as temporary in the long period after application of the complete support system. The measured data enabled the control stress-strain back analysis to confirm parameters for describing the real behaviour of excavated and reinforced rock mass. Based on the results of these back analyses, an active design procedure was established which made possible the required changes in the rock mass reinforcement system in cuts if the observations indicated unacceptable deformations.

\section{$4 \quad$ Numerical analysis of reinforced cuts in flysch rock mass}

To confirm the stability of the reinforced flysch rock mass cuts, limit state slope stability analyses and stress-strain analyses were carried out. A combination of these methods enables the understanding of reinforcement system behaviour (Arbanas, 2002; 2004; Arbanas et al., 2006a; 2006b; 2007a; 2007b). An overview of the stress-strain analyses is given for higher cuts through excavation stages and reinforcement of flysch rock mass. 
A geotechnical model was established from prognosis engineering-geological cross-sections and appropriate classifications of rock flysch mass. Each stage of the works in the numerical model was simulated as an excavation of rock mass and the installation of appropriate reinforcement system.

The geotechnical cross-section in the numerical simulation was made of cover and bedrock. The cover was made of a colluvial clayey deposits thickness from 0 to $4 \mathrm{~m}$, a weathered zone of flysch rock mass thickness from 2 to $4.5 \mathrm{~m}$. The bedrock was made of fresh siltstone flysch rock mass. Soil and rock parameters, obtained from GSI classification of flysch rock mass and laboratory testing of rocks and soils, used in stressstrain analysis are given in Table 2.

Stress-strain analyses were carried out with Sigma/W (Geo-Slope, 1998) using finite elements method. A numerical finite element model (geotechnical cross-section) is generated using quadrilateral and triangular elements with four and three nodes on edges. Behaviour of the rock mass layers (WH and F) and soil (residual soil in slope formations) is reproduced with elastic-plastic model. The rockbolts are represented by means of spring elements acting at the cut face. Spring element stiffness is obtained by executing a pull-out test on installed trial rockbolts on close locations. The stiffness of rockbolt is defined as a quotient of applied rockbolt force and measured deformation of rockbolts during the pull-out test. The geometry of the model is shown in Figure 6.

The same cross-section represented in the model was monitored during the construction.

Table 2 Deformation properties of materials in numerical model

\begin{tabular}{clccc}
\hline Layer & Soil/Rock Descriptions & Soil/Rock Model & Young’s Modulus (MPa) & Poisson Ratio \\
\hline 1 & Slope formations (RS) & Elastic-plastic & 3.50 & 0.31 \\
2 & Weathered flysch rock mass (WH) & Elastic-plastic & 8.50 & 0.31 \\
3 & Fresh flysch rock mass (F) & Elastic-plastic & 85.0 & 0.33 \\
\hline
\end{tabular}

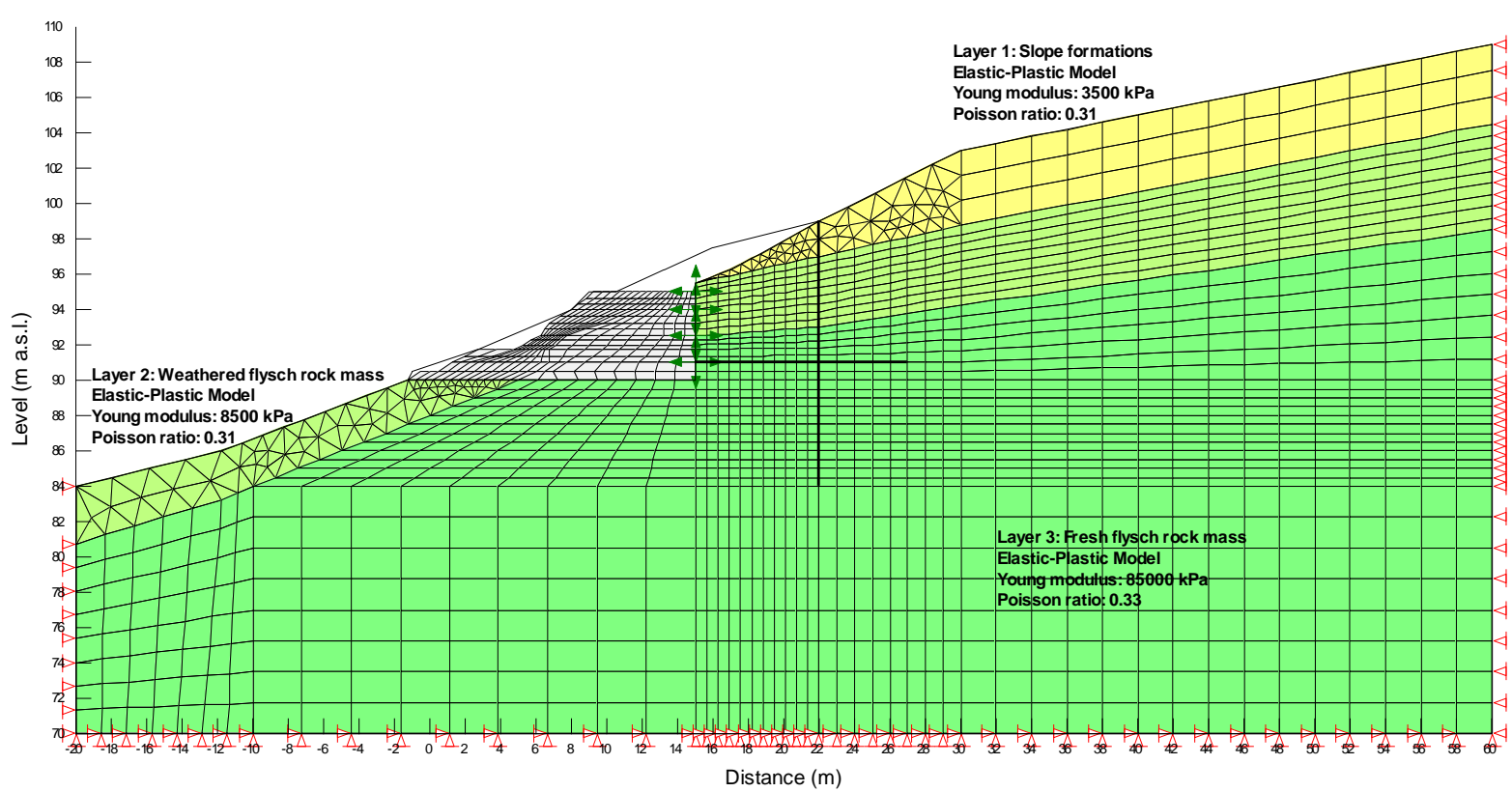

Figure 6 Finite elements model for stress-strain analyses

The displacement of cut face must correspond with deformations of the rockbolts and enable the calculation of activating forces in the rockbolts. In the following steps, it was possible to harmonise behaviour of real behaviour of reinforced cut with numerical model in an iterative process which enables the determination of deformation modules of particular layers. Figure 7 shows the distribution of the calculated horizontal displacement on the cut. 


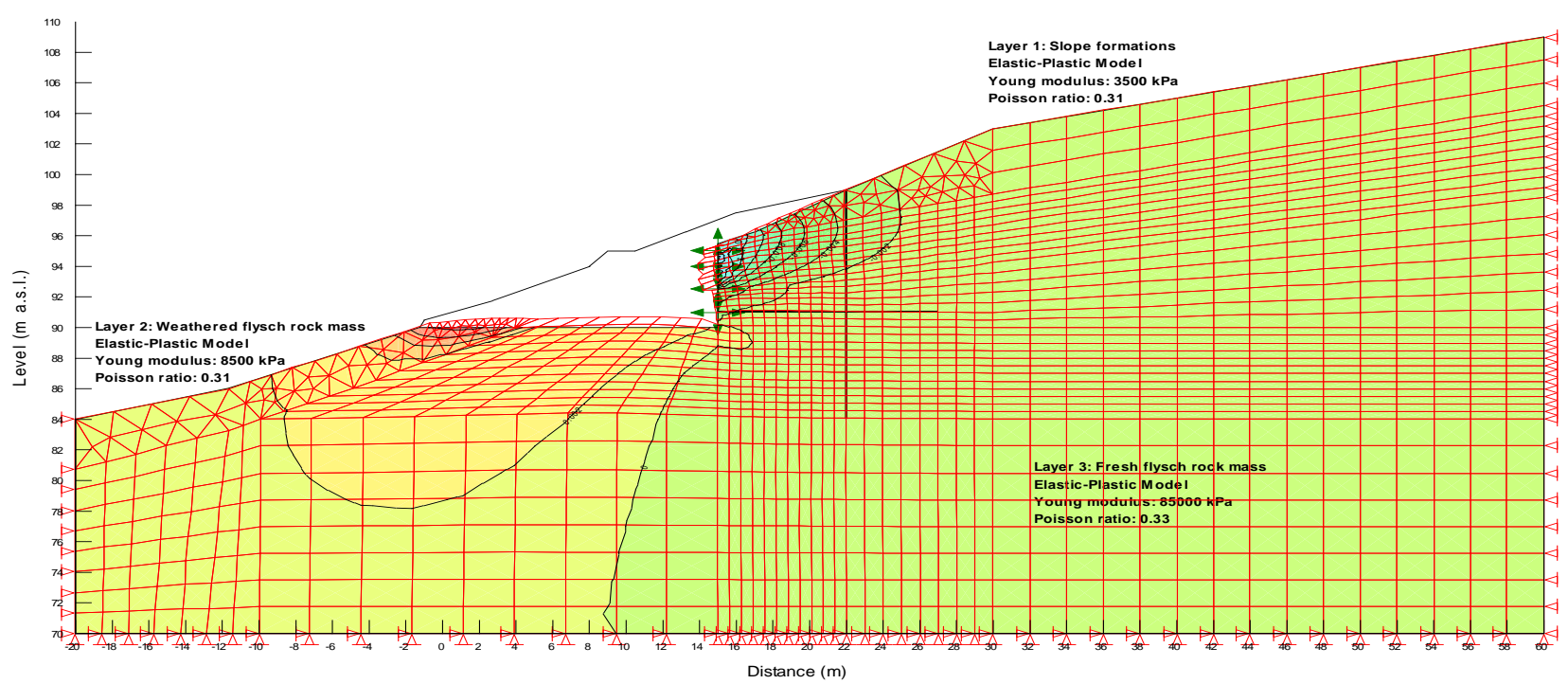

Figure 7 Deformed finite element mesh and horizontal displacements in the model

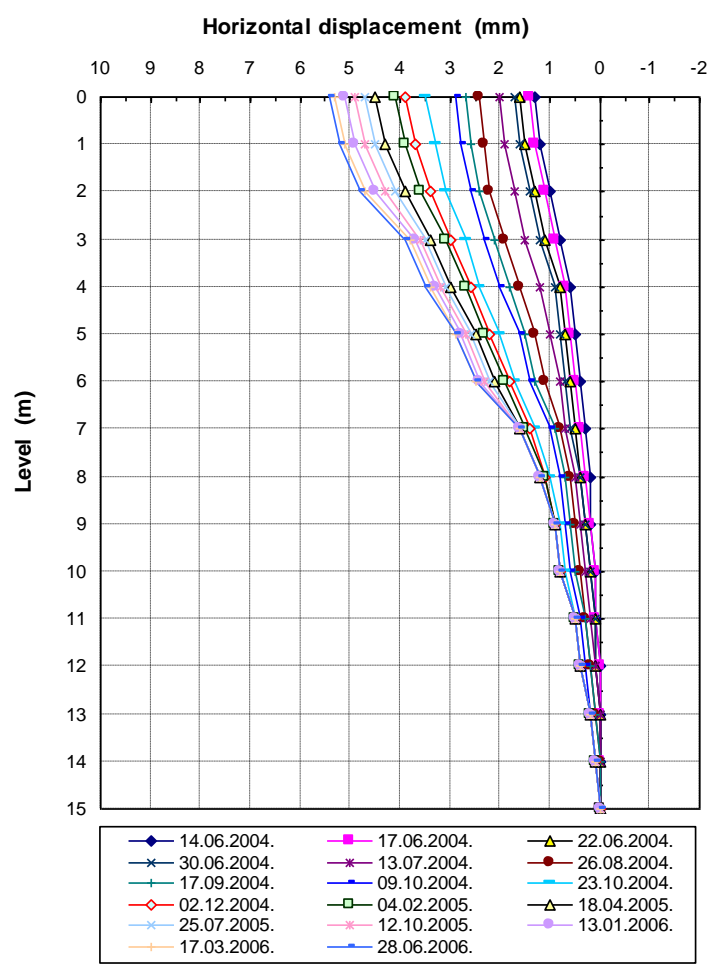

Figure 8 Measured deformations on the vertical deformeter during and after excavations

An interactive rock mass excavation cut design, based on the observational method (Terzaghi and Peck, 1967; Peck, 1969; Powderham, 1998; Nicholson et al., 1999; Kovačević and Szavits-Nossan, 2006; SzavitsNossan, 2006; Arbanas et al., 2006a) was introduced in the phase of construction. Rock mass cut design methodologies were shown by Hoek and Bray (1977) and Wyllie and Mah (2004) and have been amended to include the selection of support structures (Arbanas, 2002, 2003; Kovačević, 2003; Arbanas et al., 2006a) and the appropriate rockbolts (Stillborg, 1994). Results of measured horizontal displacements on the vertical inclinometer close to cut face are shown in Figure 8. Experimental measurements and numerical displacements were compared. This allowed the control of actual forces in rockbolts and necessity of extra reinforcement of the rock mass (Arbanas et al., 2006a; 2006b; 2007b). 
Measured strain in the vertical inclinometers-extensometers (deformeters) and horizontal extensometers (deformeters) showed a good match with the predicted calculated strain for all excavation stages. To confirm designed support system, measured and calculated deformations of the slope are compared on the positions of the vertical and inclinometers and horizontal deformeters. The chosen displacements to compare are values of calculated displacements on the face of the cut with measured extensions of the horizontal deformeters on the same place. The results of the calculated horizontal displacements on the cut during construction are shown in Figure 9. The differences between measured and calculated displacement values were less than $4 \mathrm{~mm}$ during all stages of construction. Changes in reinforcement systems were rare and mostly caused with differences between predicted and actual geological conditions.
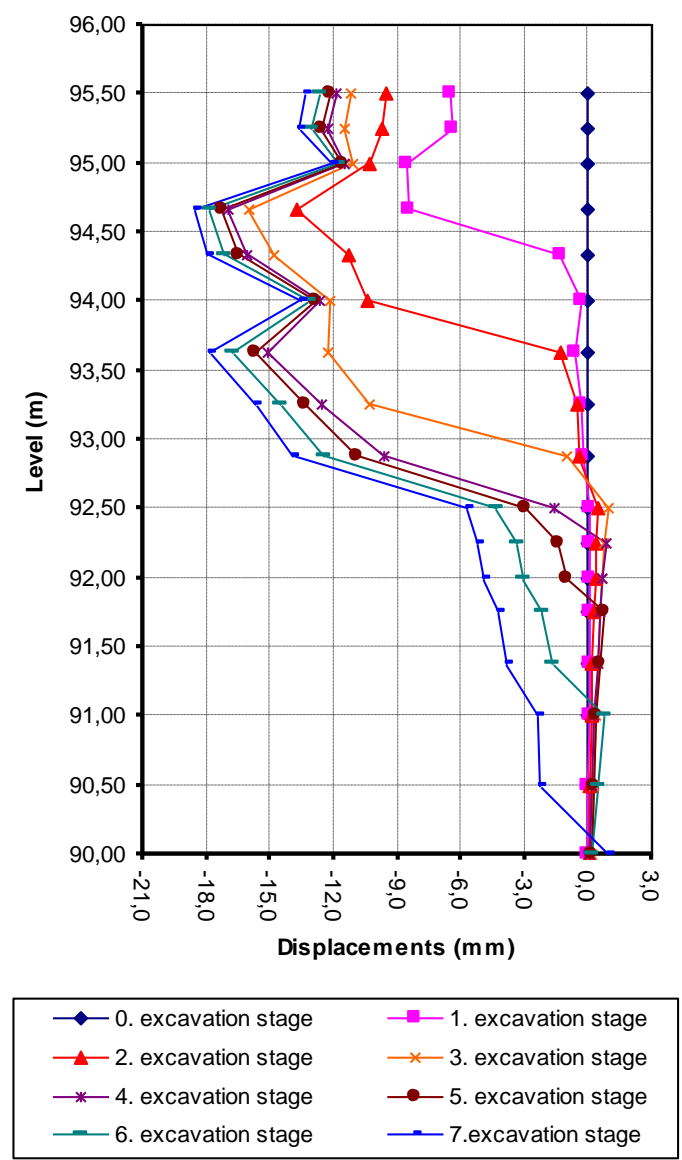

Figure 9 Calculated displacements on face of the cut during constructions

The reinforcement of the flysch rock mass on the executed cuts with designed systems was completed successfully according to the predicted design solutions. In part of the slope cut local instability occurred mostly caused by unfavourable geological conditions or because of the late installation of the rock mass reinforcement system.

During the monitoring of the cut's behaviour, a period of two years after construction, the long-term deformations were observed. The analyses indicated that the values of long-term deformations in reinforced flysch rock cuts are significant in relation to the measured values of deformations during construction. The existing comments indicated the need of further detailed investigations in the future.

\section{Conclusions}

During the period from 2004 to 2006, the section of the Adriatic motorway through the Draga Valley near Rijeka, was constructed. The geological fabric of the Draga Valley is very complex. The Cretaceous and the Paleogene limestones are situated on the top of the slope, while the Paleogene flysch crops are on the lower slope and on the bottom of the Draga Valley where the motorway is located. Unlike limestone rocks at the 
top of the slope, flysch rock mass is completely covered by colluvial deposits, residual soils and talus breccia.

For the design of the cuts on the motorway, the challenge was the determination of design parameters of soil deposits and flysch rock mass. During field investigations, it was very difficult to get undisturbed samples of disintegrated flysch rock mass. There is also a sudden degradation and disintegration of SW to F siltstones after removal of geostatic loads and exposure to air and water. To determine the uniaxial strength of rock mass, the PLT method is usually used, where samples, obtained by boring, can be used without further processing and almost immediately after sampling. Test results with the PLT method on F siltstone samples showed that uniaxial strength of these materials is from 10 to $15 \mathrm{MPa}$, and in extreme cases to $20 \mathrm{MPa}$. Determination of the shear strength criteria and deformability modulus of flysch rock mass, was based on the GSI concept. Based on recommendations from Marinos and Hoek (2001), F siltstone flysch rock mass is placed in group E to $\mathrm{H}$, with GSI values from 30 to 10 . The significant strength parameters decrease is found with increase of weathering of siltstones in flysch rock mass.

Based on the accepted parameters of soils and rock mass, the geotechnical model was developed. The stressstrain and limit state slope stability analyses, confirm the stability of reinforced cuts in flysch rock mass. The cut stability is ensured by reinforcement of the cuts by rockbolts and an appropriate supporting system. The support system was designed in two phases. The first phase was predicted rockbolt reinforcement system with multilayer sprayed concrete. In the second phase, a stiff concrete retaining construction was applied to fix relatively soft primary reinforcement system. Simultaneously with the reinforcement support system, deep drainage boreholes were drilled. The stability of the cut in the flysch rock mass, without an applied support system, is time dependent. The working stages of the primary support system were relatively very short, excavation in one day, first layer of sprayed concrete and rockbolts installation in the next two days, and additional two layers of sprayed concrete in the following two days.

During the cut construction, a measuring, observing, and monitoring system was established. The monitoring system included deformation measuring in horizontal deformeters and vertical inclinometers, and geodetic surveying, as load measuring on rockbolts instrumented by load cells. To confirm the designed support system, measured and calculated deformations of the slope are compared on the positions of the vertical and inclinometers and horizontal deformeters. Measured strain in the vertical inclinometers-extensometers (deformeters) and horizontal extensometers (deformeters) showed a good match with the predicted calculated strain for all excavation stages. The differences between measured and calculated displacement values were less than $4 \mathrm{~mm}$ during all stages of construction. Changes in reinforcement systems were rare and mostly caused by differences between predicted and actual geological conditions.

\section{References}

Arbanas, Ž., Benac, Č., Andrić, M. and Jardas, B. (1994) Geotechnical Properties of Flysch on The Adriatic Motorway from Orehovica to St. Kuzam, Proceedings Symposium Geotechnical Engineering in Transportation Projects, Croatian Geotechnical Society, Novigrad, October 5-8, pp. 181-190 (in Croatian).

Arbanas, Ž. (2002) The influence of rockbolts on the rock mass behaviour during excavation of deep cuts, MSc Thesis, Faculty of Civil Engineering, University of Zagreb (in Croatian), 207 p.

Arbanas, Ž. (2003) Construction of open pit Zagrad in Rijeka, Građevinar, Vol. 55, No. 10, pp. $591-597$ (in Croatian).

Arbanas, Ž. (2004) Prediction of supported rock mass behaviour by analysing results of monitoring of constructed structures, PhD Thesis, Faculty of Civil Engineering, University of Zagreb (in Croatian), 220 p.

Arbanas, Ž., Kovačević, M.-S. and Szavits-Nossan, V. (2006a) Interactive design for deep excavations, Proceedings XIII Danube-European Conference on Geotechnical Engineering, Active Geotechnical Design in Infrastructure Development, J. Logar, A. Gaberc and B. Majes (editors), Slovenian Geotechnical Society, Ljubljana, May 2931, Vol. 2, pp. 411-416.

Arbanas, Ž., Grošić, M. and Jurić-Kaćunić, D. (2006b) Influence of grouting and grouting mass properties on reinforced rock mass behaviour, Proceedings 4th Conference of the Croatian Geotechnical Society, Soil and Rock Improvement, Opatija, V. Szavits-Nossan and M.S. Kovačević (editors), Croatian Geotech. Society, Zagreb, 5-7 October, pp. 55-64.

Arbanas, Ž., Grošić, M. and Jurić-Kaćunić, D. (2007a) Experiences on flysch rock mass reinforcing in engineered slopes, The Second Half Century of Rock Mechanics, Proceedings 11th Congress of the Int. Society for Rock Mechanics, Lisbon, Portugal, July 9-13, Taylor and Francis Group, London, pp. 597-600.

Arbanas, Ž., Grošić, M. and Kovačević, M.-S. (2007b) Rock mass reinforcement systems in open pit excavations in urban areas, Slope Stability 2007, Proceedings 2007 Int. Symp. on Rock Slope Stability in Open Mining and 
Civil Engineering, Perth, Australia, September 12-14, Y. Potvin (editor), Australian Centre for Geomechanics, Perth, pp. 171-185.

GEO-Slope Int. Ltd (1998) User's Guide Slope/W for Slope Stability Analysis, Version 4, Calgary.

Hoek, E. (1994) Strength of Rock and Rock Masses, ISRM News Journal, Vol. 2, (2), pp. 4-16.

Hoek, E. and Bray, J.W. (1977) Rock Slope Engineering, 2nd Edition, The Institute of Mining and Metallurgy, London, $527 \mathrm{p}$.

Hoek, E., Carranza-Torres, C.T. and Corkum, B. (2002) Hoek-Brown Failure Criterion, 2002 Edition, Proceedings 5th North American Rock Mechanics Symposium, Toronto, Canada, Dept. Civ. Engineering, University of Toronto, pp. 267-273.

Hoek, E., Kaiser, P.K. and Bawden, W.F. (1995) Support of Underground Excavations in Hard Rock, A.A. Balkema, Rotterdam, $215 \mathrm{p}$.

Hoek, E., Marinos, P. and Benissi, M. (1998) Applicability of the Geological Strength Index (GSI) Classification for Very Weak and Sheared Rock Masses. The Case of the Athens Shist Formation. Bull. Eng. Geol. Env., No. 57, pp. $151-160$.

ISRM, Commission on Standardization of Laboratory and Field Test (1981a) Suggested Methods for the Rock Characterization, Testing and Monitoring, E.T. Brown (editor), Pergamon Press, Oxford, UK, 211p.

ISRM, Commission on Standardization of Laboratory and Field Test (1981b) Suggested Methods for the Quantitative Description of Discontinuities in Rock Masses, E.T. Brown (editor), Pergamon Press, Oxford, UK, $211 \mathrm{p}$.

ISRM, Commission on Standardization of Laboratory and Field Test (1985) Suggested Methods for Determining Point Load Strength, Int. Jour. Rock Mech. Min. Sci. \& Geomech. Abstr., Vol. 22, No. 2, pp. 51-60.

Kovačević, M.-S. (2003) The Observational Method and the Use of Geotechnical Measurements. Geotechnical problems with man-made and man influenced grounds, Proceedings 13th European. Conference on Soil Mechanics and Geotechnical Engineering, Prague, Czech Republic, August 25-28, Vol. 3, pp. 575-582.

Kovačević, M.-S. and Szavits-Nossan, V. (2006) Interactive design - Croatian experience, Proceeding of XIII DanubeEuropean Conference on Geotechnical Engineering, Active Geotechnical Design in Infrastructure Development, J. Logar, A. Gaberc and B. Majes (editors), Slovenian Geotechnical Society, Ljubljana, May 29-31, Vol. 2, pp. $451-455$.

Marinos, P. and Hoek, E. (2000) GSI: A geologically friendly tool for rock mass strength estimation, Proceedings GeoEng 2000 at the international conference on geotechnical and geological engineering, Melbourne, Technomic publishers, Lancaster, pp. 1422-1446.

Marinos, P. and Hoek, E. (2001) Estimating the Geotechnical Properties of Heterogeneous Rock Masses such as Flysch. Bull. Eng. Geol. Env., No. 60, pp. 85-92.

Marinos, V., Marinos, P. and Hoek, E. (2005) The geological strength index: applications and limitations, Bull. Eng. Geol. Environ, No. 64, pp. 55-65.

Nicholson, D.P., Tse, C.M. and Penny, C. (1999) The Observational Method in Ground Engineering: Principles and Applications, Report 185, CIRIA, London.

Peck, R.B. (1969) Advantages and limitations of the observational method in applied soil mechanics, Géotechnique, Vol. 19 (2), pp. 171-187.

Powderham, A.J. (1998) The observational method-application through progressive modification. Civil Engineering Practice, Journal of the Boston Society of Civil Engineers Section/ASCE, Vol. 13 (2), pp. 87-110.

Stillborg, B. (1994) Professional Users Handbook for Rock Bolting, Trans Tech Publications, Series on Rock and Soil Mechanics, Vol. 18, 2nd Edn., Clausthal-Zellerfeld, 164 p.

Szavits-Nossan, A. (2006) Observations on the observational Methods, Proceeding XIII Danube-European Conference on Geotechnical Engineering, Active Geotechnical Design in Infrastructure Development, J. Logar, A. Gaberc and B. Majes (editors), Slovenian Geotechnical Society, Ljubljana, May 29-31, Vol. 1, pp.171-178.

Terzaghi, K. and Peck, R.B. (1967) Soil Mechanics in Engineering Practice. John Wiley, New York.

Wyllie, D.C. and Mah, C.W. (2004) Rock Slope Engineering, Civil and Mining, 4th. Edn., Spon Press, New York, Taylor \& Francis Group, 431 p. 
